\title{
Using critical analysis to develop metacognitive ability and critical thinking skills in biology
}

\author{
Marheny Lukitasari a,1, Rusdi Hasan b,2,*, Wasilatul Murtafiah c,3 \\ a Department of Biology Education, Universitas PGRI Madiun, Jl. Setia Budi No. 85 Madiun, East Java 63118, Indonesia \\ ${ }^{b}$ Department of Biology Education, Universitas Muhammadiyah Bengkulu, Kampus I Jl. Bali, Teluk Segara, Bengkulu 38119, Indonesia \\ c Department of Mathematics Education, Universitas PGRI Madiun, JI. Setia Budi No. 85 Madiun, East Java 63118, Indonesia \\ ${ }^{1}$ marh33ny@gmail.com; ${ }^{2}$ rusdihasan@umb.ac.id*; ${ }^{3}$ wasila.mathedu@unipma.ac.id \\ * corresponding author
}

\begin{tabular}{|c|c|}
\hline ARTICLE INFO & ABSTRACT \\
\hline $\begin{array}{l}\text { Article history } \\
\text { Received December 25, } 2018 \\
\text { Revised February 16, } 2019 \\
\text { Accepted February 23, } 2019 \\
\text { Published March 09, } 2019 \\
\text { Keywords } \\
\text { Critical analysis } \\
\text { Critical thinking skill } \\
\text { Metacognitive ability }\end{array}$ & $\begin{array}{l}\text { Possessing and developing metacognitive abilities are an essential part of the learning } \\
\text { process. This study is a class action research on the use of critical analysis to identify } \\
\text { its influence on students' metacognitive abilities and critical thinking skills as well as to } \\
\text { discover the relationship between metacognitive abilities and critical thinking skills. The } \\
\text { sample of this study is } 76 \text { students from } 217 \text { students taking cell biology and non- } \\
\text { vascular plants subject during the fall semester. It is a descriptive quantitative study with } \\
\text { critical analysis assignments. Critical analysis rubric is used to collect the data of } \\
\text { students' critical analysis and the essay test to measure students' critical thinking and } \\
\text { metacognitive ability. The data of metacognitive ability and critical thinking were } \\
\text { analyzed using regression test. The result showed there was a positive influence of the } \\
\text { use of critical analysis to the student metacognitive abilities and critical thinking skills. } \\
\text { The results of a simple correlation analysis of metacognitive abilities and critical thinking } \\
\text { skills show the means value (r) of } 0.904 \text {, which means that there is a strong positive } \\
\text { relationship between the two components. The higher the student' metacognitive skills, } \\
\text { the higher their critical thinking skill will be. }\end{array}$ \\
\hline
\end{tabular}

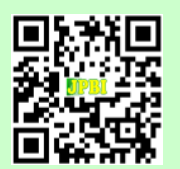

Copyright $\odot$ 2019, Lukitasari et al This is an open access article under the CC-BY-SA license

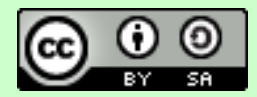

How to cite: Lukitasari, M., Hasan, R., \& Murtafiah, W. (2019). Using critical analysis to develop metacognitive ability and critical thinking skills in biology. JPBI (Jurnal Pendidikan Biologi Indonesia), 5(1), 151-158. doi: https://doi.org/10.22219/jpbi. v5i1.7262

\section{INTRODUCTION}

Attention needs to be given to the output profile of graduates who recognize their condition to support their abilities in the higher education learning process. Recognizing the ability to learn, remember, motivate themselves and conditioning a learning activity support this potential. Schraw et al. (1995) defined this ability as a metacognitive ability, which includes knowledge related to strategy, tasks, and cognitive understanding. Planning, monitoring, and evaluation are important activities that need to be performed during the learning process to review metacognitive abilities that reflect mental processes (Hanten et al., 2004; Karsli, 2015). Spada and Roarty (2015) showed the relationship between metacognitive abilities and cognitive selfconfidence, the ability to predict and improve self-focus. On the other hand, the concept of critical thinking is also another critical issue during the learning process that needs to be developed. 
Possessing and developing metacognitive abilities are an essential part of the learning process since these abilities are in connection to the confidence and independence of the student to arrange planning, conduct an evaluation and make a decision (Weil et al., 2013). Critical thinking as stated by Cojocariu and Butnaru (2014) is an essential component in modern education. It has an advantage in understanding and developing the dimension of thinking. Following the basis of Bloom's cognitive taxonomy, critical thinking is the highest domain that refers to the analysis, synthesis, and evaluation abilities.

The student can practice their critical thinking skills in many ways to produce active learning atmosphere in the class. Forming small groups and practising structured assignments are two important parts to develop metacognitive abilities (Wilson, 2017).

Laisema and Wannapiroon (2014) and (Rahimi \& Masoud, 2015) showed that many components or instruments could be used to develop critical and creative thinking skills, and one of them is a critical analysis. Lukitasari et al. (2014) outlined that critical analysis in electronic form can help students to manage and understand the essential point from their reading easily. Busmin (2010) showed that using critical analysis affects the ability to interpret and conduct analysis to find the meaning of the text and the contents of the reading. Furthermore, Karami et al. (2012), Kirmizi et al. (2015) and Thaiposri and Wannapiroon, 2015) in the results of their research stated that critical thinking skills could be influenced by learning methods and applied curriculum. Thus, the use of critical analysis as a tool to support learning is very useful and can be applied in higher education.

Since the metacognitive skills to master in activities of planning and to evaluate the learning outcomes independently has not optimally trained yet in the learning process, students are unaware of the importance of these abilities as a reflection to their learning outcome. It shows that metacognitive abilities have not been structurally developed to give a positive impact on learning outcomes. Whereas, as stated by Bernard et al. (2008), learning how to think is the primary goal of formal education. The development of metacognitive abilities closely related to the development of other essential abilities as critical thinking skills.

Developing metacognitive abilities as well as critical thinking skills is crucial in learning. The critical analysis (critical discourse analysis) can benefit as an option to practice and to develop metacognitive abilities as well as critical thinking skills. The results of the study by Magno (2010) showed that metacognitive abilities gave significant results to students' critical thinking abilities. The instrument was to use the preparation of critical analysis by reviewing and looking at the readings to retrieve the contents of relevant reading. Arifin (2012) added that the supporting components in critical thinking instruments compiled and applied in learning would optimize students' personality development, reasoning and acting abilities.

Based on that condition, the metacognitive abilities and critical thinking skills have not yet been practised optimally and students have not been accustomed to the practice. The increase of these abilities is an integral part that necessary to be developed continuously to build students confidence and competency. Therefore, this study subjected: 1) to identify the effect of using critical analysis on students 'metacognitive abilities, 2) to discover the effect of using critical analysis on students' critical thinking skills, and 3) to discover the relationship between metacognitive abilities and critical thinking skills.

\section{METHOD}

\section{Research design}

This study was quantitative research with data analyzed by using SPSS version 16 . The independent variable in this study was the provision of critical analysis assignments for students. The dependent variables in this study were metacognitive abilities (y1) and critical thinking skills (y2). Figure 1 shows the research design in this study.

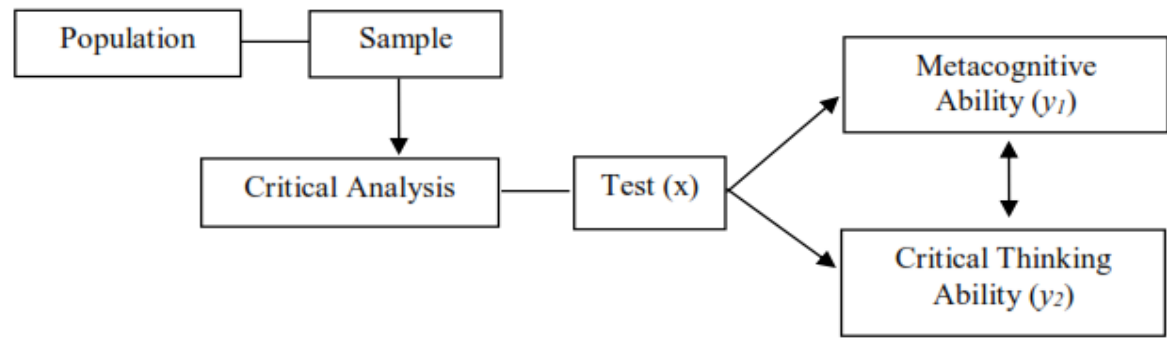

Figure 1. Research design (Gunawan, 2013) 
The study was conducted in the even semester of the 2014-2015 academic year from June to August 2015 in the subjects of non-vascular plant and cell biology. The research was performed in the Department of Biology Education of PGRI University of Madiun, Indonesia. The sample of this study were 76 students from 217 population of second-semester students.

The data instruments used in this study were rubric of critical analysis (Table 1) and ten items of essay tests. The tests delivered twice with two different instruments to measure the student metacognitive abilities and critical thinking skills. The essay test instrument initially consisted of thirteen questions. Based on the validity and reliability test from the pretest and posttest as well as the revision process, only ten were used as valid and reliable items for further analysis.

\section{Research procedures}

The student performed a critical analysis on the reading of a particular topic in this research individually or by groups. Critical analysis was conducted in eight meetings for each class. The students' reading analysis comes from two sources, the handbook and the international journal related to the material discussed during lectures. The form of critical analysis and the scoring guideline consisted of the following components can be seen in Table 1.

Table 1. Criteria of critical analysis and score

\begin{tabular}{lc}
\hline Criteria & Score \\
\hline Providing Identity & 1 \\
a. Group's Member names & 1 \\
b. Class/ID Number & 1 \\
c. Source & 2 \\
d. Reading Theme & 5 \\
\hline Sub-Score & 5 \\
\hline The objective of Critical Analysis Delivery & 5 \\
a. The objectives are relevant to what the writer meant & 10 \\
b. Correct and Clear Grammar & 10 \\
\hline Sub Score & 10 \\
\hline The unique fact presented & 20 \\
a. The crucial concepts from the reading & 40 \\
b. Pictures or grafts that supported the reading & 5 \\
c. Present the correlation between concept and reading material & 10 \\
\hline Subscore & 15 \\
\hline Statement that can be addressed & 5 \\
a. Present more than 2 questions & 5 \\
b. Present a question for C3-C5 class & 5 \\
\hline Subscore & 5 \\
\hline Reflection & 5 \\
a. Write down what has been understood from the reading & 20 \\
b. Write down what has not been understood from the reading & 100 \\
c. Write down the future plan & \\
d. Correct and clear grammar & 10 \\
\hline Subscore & \\
\hline Total score & \\
\hline
\end{tabular}

The scoring indicator of essay test in determining students' critical thinking skills followed Averkieva et al. (2015) and Arifin (2012), as follow: 1) grammar, 2) completeness, 3) consistency of information delivered, 4) creativity 5) defining, 6) developing information and 7) conveying arguments. Table 2 presents the indicator and description of critical thinking skill of student possess.

Table 2. Indicator and the description of critical thinking skill

\begin{tabular}{ll}
\hline \multicolumn{1}{c}{ Indicator } & \multicolumn{1}{c}{ Description } \\
\hline Grammar & Clear sentence structure and well structured. \\
Completeness & Completed all the assignments of critical analysis \\
The consistency of information presented & Correlation between supporting information based on the analysis. \\
Creativity & The development of material logically and based on the fact \\
Defining & Explanation of terms and understanding \\
Developing information & Develop material based on the relevant sources \\
\hline
\end{tabular}


The results of the critical analysis are based on the answers of the essay test which then measured using rubrics on a 1-4 scale (Arifin, 2012; Averkieva et al., 2015). The scores and the criteria were as follows: 1 point for unclear, 2 points for less clear, 3 points for clear, and 4 points for very clear. The main data source was the essay test, which consisted of what the lecturer created and given at the end of the discourse. Students completed two different instruments of essay test to obtain data of metacognitive and critical thinking skills.

\section{Data analysis}

Metacognitive ability measurement followed the score and rubric from Corebima (2009) using Formula 1.

$Y 1=\frac{X+2 Y 2}{3}$

$Y 1$ is a combination score that comes from an essay test and metacognitive skills. The resulting score was then adjusted to a particular rubric. $X$ is a metacognitive ability score. $Y 2$ is the score of the essay test results. Data of metacognitive abilities and critical thinking skills were then analyzed by using SPSS version 16 .

\section{RESULTS AND DISCUSSION}

The analysis of metacognitive abilities and critical thinking skills started with a preliminary test which included the normality test, heteroscedasticity test, autocorrelation test (Durbin-Watson), and multicollinearity test. After all precondition tests have been fulfilled, then the correlation tests and simple linear regression test can be seen in Table 3.

Table 3. Preliminary Test Result

\begin{tabular}{|c|c|c|c|c|}
\hline \multirow{2}{*}{ Test } & \multicolumn{4}{|c|}{ Significant/Output } \\
\hline & Metacognitive Ability & Information & Critical Thinking & Information \\
\hline Normality & $0.165>0.05$ & Normal & $0.176>0.05$ & Normal \\
\hline Heteroscedasticity & $0.925>0.05$ & $\begin{array}{l}\text { No heteroscedasticity } \\
\text { problem }\end{array}$ & $0.237>0.05$ & $\begin{array}{l}\text { No heteroscedasticity } \\
\text { problem }\end{array}$ \\
\hline $\begin{array}{l}\text { Autocorrelation } \\
\text { (Durbin-Watson) }\end{array}$ & $\begin{array}{c}2.005>1.654 \text { (table } \\
\text { Durbin-Watson) }\end{array}$ & $\begin{array}{l}\text { No Autocorrelation } \\
\text { Problem }\end{array}$ & $1.937>1.654$ & $\begin{array}{l}\text { No Autocorrelation } \\
\text { Problem }\end{array}$ \\
\hline Multicollinearity & $\begin{array}{c}\text { Tolerance }>0.1 \text { and } \\
\text { Variance inflation factor } \\
(\text { VIF })<10 \text {. }\end{array}$ & $\begin{array}{l}\text { No Multicollinearity } \\
\text { problem }\end{array}$ & $\begin{array}{l}\text { Tolerance }>0.1 \text { and } \\
\text { Variance inflation } \\
\text { factor }(\mathrm{VIF})<10 .\end{array}$ & $\begin{array}{l}\text { No Multicollinearity } \\
\text { problem }\end{array}$ \\
\hline
\end{tabular}

The results of the preliminary test in Table 3 shows that all preliminary test assumptions were fulfilled. Hence, the further test was performed as shown in Table 4.

Table 4. Further test result

\begin{tabular}{|c|c|c|c|c|}
\hline \multirow{2}{*}{ Output } & \multicolumn{2}{|c|}{ Metacognitive Ability } & \multicolumn{2}{|c|}{ Critical Thinking } \\
\hline & Significant Score & Information & Significant Score & Information \\
\hline $\begin{array}{l}\text { Correlation coefficient in } \\
\text { summary model y }\end{array}$ & 0.525 & $\begin{array}{l}\text { There is } \\
\text { correlation }\end{array}$ & 0.982 & There is correlation \\
\hline ANOVA & $0.00<0.05$ & Significant & $0.00<0.05$ & Significant \\
\hline Coefficient & $0.00<0.05$ & There is effect & $0.00<0.05$ & There is effect \\
\hline
\end{tabular}

The results of the further test in Table 4 show the correlation coefficient of 0.525 means that there was a relationship between critical analysis and metacognitive abilities. There was a significant relationship between the use of critical analysis and metacognitive abilities. While critical thinking skills showed a mean correlation coefficient value of 0.982 , there was a relationship between critical analysis and critical thinking skills. The result of the coefficient shows $0.00<0.05$, which means that there was a significant relationship between critical analysis and critical thinking skills. Furthermore, Table 5 shows the relationship between metacognitive abilities and critical thinking skills. 
Table 5. The correlation between metacognitive ability and critical thinking skill

\begin{tabular}{llcc}
\hline \multicolumn{2}{c}{ Correlations } & Metacognitive Ability & Critical Thinking Skill \\
\hline Metacognitive Ability & Pearson Correlation & 1 & $.904^{* *}$ \\
& Sig. (2-tailed) & & .000 \\
& $\mathrm{~N}$ & 76 & 76 \\
\hline Critical Thinking Skill & Pearson Correlation & $.904^{* *}$ & 1 \\
& Sig. (2-tailed) & .000 & 76 \\
& $\mathrm{~N}$ & 76 & \\
\hline
\end{tabular}

**. Correlation is significant at the 0.01 level (2-tailed).

The simple correlation analysis between metacognitive abilities and critical thinking skills showed the value ( $r$ ) of 0.904 with a positive direction, meaning that there was a strong relationship between the two. This proves Sugiyono's (2007) suggestion that the higher the metacognitive ability, the higher critical thinking skills were.

Correlation test from the use of critical analysis of metacognitive abilities and critical thinking skills showed a significant result. Thus, the use of critical analysis had a significant effect on metacognitive abilities and critical thinking skills. For metacognitive abilities that focus on planning, implementing and evaluating, the use of critical analysis helped students to improve their experience significantly (Veenman, Wilhelm, \& Beishuizen, 2004; Yaliz, 2014). The components of the question in critical analysis encourage the development of complexity of thinking so that students can plan and complete the task given while evaluating errors that might occur (Hattie \& Donoghue, 2016; Helyer, 2015; Scottish Qualifications Authority, 2017; Tofade, Elsner, \& Haines, 2013; Zeichner, 2008).

Learning experiences related to metacognition were a series of accelerated cognitive abilities that can be continuously developed (Ellis, Denton, \& Bond, 2014; Gurubatham, 2013; Spada \& Roarty, 2015).

The continuity of critical analysis application during lectures in Biology Cell and the Non-vascular Plant Taxonomy made students accustomed to planning, performing analysis while evaluating the mistake. Students appeared to be more sensitive when there were errors that included content and grammar, conveyed the results in the presentation and conducted evaluation. Cox (2005) and Hrbakova et al. (2012) show the argumentation of the results on their research that habituation was a crucial thing to practice metacognition because it made students accustomed to identifying the problems, presentations, arranging plans and solving problems.

Currently, developing metacognitive abilities continuously are an essential component in the education system to support the learning process (Whitebread et al., 2009). The use of supporting instruments in the form of tasks such as critical analysis is useful to encourage students in achieving the learning goals (Bhagat, Vyas, \& Singh, 2015; Le, Janssen, \& Wubbels, 2018; Sung, Chang, \& Liu, 2016). On the other hand, the increased ability in planning, implementing and evaluating critical analysis of completed tasks made students' confidence to improve. An increase in student confidence is the result of self-support and motivation as they have completed their work on critical analysis well (Alper et al., 2015; Gurbin, 2015; Lukitasari et al., 2014).

The use of critical analysis helped students to find essential parts of the material in the reading structure. There was a uniqueness found in this study that students tend to be more careful to fill in every vital component in the critical analysis writing. It appears from the results of the worksheet they submitted. The students become more detail in revealing which part of the concept that they have understood and which they have not. Students implement the process of critical thinking using cognitive abilities directly was not opposing to those delivered by Alper et al. (2015) and Thaiposri and Wannapiroon (2015).

On the other hand, the existence of question sentences in the structure of critical analysis makes students able to focus on the details of the material better. Students also appear to be able to develop critical thinking skills regarding the questions they raise. When they were re-confirmed, students can provide relevant arguments related to the question. This condition is as stated in the results of the research by Cojocariu \& Butnaru (2014) and Wannapiron (2014) that the condition of high critical thinking skills usually begins with the emergence of questions which makes it easier to find answers and then develops solutions finding, arguing, interpreting and evaluating. 


\section{CONCLUSION}

The results showed that metacognitive abilities firmly related to critical thinking skills. It proves that habitual use of critical analysis made students able to develop these two abilities simultaneously. Thus, the development of metacognitive abilities is an important point to facilitate the improvement of other capabilities, which in this case includes critical thinking skills.

\section{REFERENCES}

Alper, A., Karakaya, F. A., \& Yilmaz, K. (2015). Relations between self-leadership and critical thinking skills. Procedia-Social and Behavioral Sciences, 217, 29-41. doi: https://doi.org/10.1016/j.sbspro.2015.10.147

Arifin, Z. (2012). Evaluasi pembelajaran. Bandung: Rosda Karya. Retrieved from http://winarno.staff. iainsalatiga.ac.id/wp-content/uploads/sites/25/2013/01/34-Evaluasi-Pembelajaran.pdf

Averkieva, L., Chayka, Y., \& Glushkov, S. (2015). Web quest as a tool for increasing students' motivation and critical thinking development. Procedia-Social and Behavioral Sciences, 206, 137-140. doi: https://doi. org/10.1016/j.sbspro.2015.10.042

Bhagat, A., Vyas, R., \& Singh, T. (2015). Students awareness of learning styles and their perceptions to a mixed method approach for learning. International Journal of Applied \& Basic Medical Research, 5(Suppl 1), S58-65. doi: https://doi.org/10.4103/2229-516X.162281

Bernard, R. M., Zhang, D., Abrami, P. C., Sicoly, F., Borokhovski, E., \& Surkes, M. A. (2008). Exploring the structure of the Watson-Glaser critical thinking appraisal: one scale or many subscales? Thinking Skills and Creativity, 3, 15-22. doi: https://doi.org/10.1016/j.tsc.2007.11.001

Busmin, G. (2010). Analisis wacana kritis; analisis bahasa berdasarkan fungsi sosial. Retrieved from http://digilib.unimed.ac.id/id/eprint/248

Cojocariu, V. M., \& Butnaru, C. E. (2014). Asking question-critical thinking tools. Procedia-Social and Behavioral Sciences, 128, 22-28. doi: https://doi.org/10.1016/j.sbspro.2014.03.112

Corebima, A. D. (2009). Metacognitive skill measurement integrated in achievement test. In Third International Conference on Science and Mathematics Education(CoSMEd). Penang, Malaysia. Retrieved from http://ftp.recsam.edu.my/cosmed/cosmed09/AbstractsFullPapers2009/Abstract/Science\%20Parallel\%20 PDF/Full\%20Paper/01.pdf

Cox, M. T. (2005). Metacognition in computation: a selected research review. Artificial Intelegence, 169, $104-$ 141. doi: https://doi.org/10.1016/j.artint.2005.10.009

Ellis, A. K., Denton, D. W., \& Bond, J. B. (2014). An analysis of research on metacognitive teaching strategies. In Procedia Social and Behavioral Sciences, 116, 4015-4024. doi: https://doi.org/10.1016/j.sbspro. 2014.01.883

Gunawan, M., A. (2013). Statistik untuk penelitian pendidikan. Yogyakarta: Parama Publishing. Retrieved from https://scholar.google.com/scholar?cluster=16603341076592461691\&hl=en\&oi=scholarr

Gurbin, T. (2015). Metacognition and technology adoption: exploring influences. In Procedia-Social and Behavioral Science, 191, 1576-1582. doi: https://doi.org/10.1016/j.sbspro.2015.04.608

Gurubatham, M. R. (2013). Blended action learning involving metacognition and active discussion on internationally. In Procedia-Social and Behavioral Science, 93, 2157-2172. doi: https://doi.org/10.1016 jj.sbspro.2013.10.182

Hanten, G., Dennis, M., Zhang, L., Barnes, M., Roberson, G., Archibald, J., ... Levin, H. S. (2004). Childhood head injury and metacognitive processes in language and memory. Developmental Neuropsychology, 25(1-2), 85-105. doi: https://doi.org/10.1080/87565641.2004.9651923

Hattie, J. A. C., \& Donoghue, G. M. (2016). Learning strategies: A synthesis and conceptual model. Npj Science of Learning, 16013(2016), 1-13. doi: https://doi.org/10.1038/npjscilearn.2016.13

Helyer, R. (2015). Learning through reflection: The critical role of reflection in work-based learning (WBL). Journal of Work-Applied Management, 7(1), 15-27. doi: https://doi.org/10.1108/JWAM-10-2015-003

Hrbakova, K., Hladik, J., \& Vavrova, S. (2012). The relationship between locus of control, metacognition, and academic succes. In Procedia-Social and Behavioral Science, 69, 1805-1811. doi: https://doi.org/10. 1016/j.sbspro.2012.12.130

Karami, M., Pakmehr, H., \& Aghili, A. (2012). Another view to importance of teaching methods in curriculum: collaborative learning and students' critical thinking disposition. In Procedia-Social and Behavioral Science, 46, 3266-3270. doi: https://doi.org/10.1016/j.sbspro.2012.06.048 
Karsli, T. A. (2015). Meta-cognition and locus of control in university students in context of viewpoint to rape. In Procedia Social and Behavioral Sciences, 205(May), 48-52. doi: https://doi.org/10.1016/j.sbspro. 2015.09.010

Kirmizi, F. S., Saygi, C., \& Yurdakal, I. H. (2015). Determine the relationship between the disposition of critical thinking and the perception about problem solving skills. In Procedia-Social and Behavioral Science, 191, 657-661. doi: https://doi.org/10.1016/j.sbspro.2015.04.719

Laisema, S., \& Wannapiroon, P. (2014). Design of collaborative learning with creative problem-solving process learning activities in a ubiquitous learning environment to develop creative thinking skills. In Procedia-Social and Behavioral Sciences, 116, 3921-3926. doi: https://doi.org/10.1016/j.sbspro.2014. 01.867

Le, H., Janssen, J., \& Wubbels, T. (2018). Collaborative learning practices: teacher and student perceived obstacles to effective student collaboration. Cambridge Journal of Education. doi: https://doi.org/10. 1080/0305764X.2016.1259389

Lukitasari, M., Susilo, H., \& Corebima, A. D. (2014). Lesson study in improving the role of e-portfolio on the metacognitive skill and concept comprehension: A study on Cell Biology subject in IKIP PGRI Madiun, Indonesia. American Journal of Educational Research, 2(10), 919-924. doi: https://doi.org/10.12691/ education-2-10-11

Magno, C. (2010). The role of metacognitive skills in developing critical thinking. Metacognition Learning, 5, 137-156. doi: https://doi.org/10.1007/s11409-010-9054-4

Rahimi, E., \& Masoud, S. (2015). Critical discourse analysis and its implication in english language teaching: a case study of political text. Journal of Linguistics and Literature, 5(3), 504-511. doi: https://doi.org/10. $17507 /$ tpls.0503.08

Schraw, G., Moshman, D., Schraw, G., \& Moshman, D. (1995). Metacognitive theories. Educational Psychology Review, 7(4), 351-371. Retrieved from https://digitalcommons.unl.edu/cgi/viewcontent.cgi? article $=1040 \&$ context=edpsychpapers

Scottish Qualifications Authority. (2017). Guide to assessment. Glasgow: Scottish Qualifications Authority The. Retrieved from https://www.sqa.org.uk/files_ccc/Guide_To_Assessment.pdf

Spada, M. M., \& Roarty, A. (2015). The relative contribution of metacognitions and attentional control to the severity of gambling in problem gamblers. Addictive Behaviours Reports, 1, 7-11. doi: https://doi.org/10. 1016/j.abrep.2015.02.001

Sugiyono. (2008). Metode Penelitian pendidikan: (pendekatan kuantitatif, kualitatif, dan R\&D). Bandung: Alfabeta. Retrieved from https://scholar.google.com/scholar?cluster=10328650190657588078\&hl=en\& oi=scholarr

Sung, Y. T., Chang, K. E., \& Liu, T. C. (2016). The effects of integrating mobile devices with teaching and learning on students' learning performance: A meta-analysis and research synthesis. Computers and Education, 94, 252-275. doi: https://doi.org/10.1016/j.compedu.2015.11.008

Thaiposri, P., \& Wannapiroon, P. (2015). Enhancing students' critical thinking skills through teaching and learning by inquiry-based learning activities using social network and cloud computing. Procedia-Social and Behavioral Sciences, 174, 2137-2144. doi: https://doi.org/10.1016/j.sbspro.2015.02.013

Tofade, T., Elsner, J., \& Haines, S. T. (2013). Best practice strategies for effective use of questions as a teaching tool. American Journal of Pharmaceutical Education, 77(7), 1-9. doi: https://doi.org/10.5688/ ajpe 777155

Veenman, M. V. J., Wilhelm, P., \& Beishuizen, J. J. (2004). The relation between intellectual and metacognitive skills from a developmental perspective. Learning and Instruction, 14(1), 89-109. doi: https://doi.org/10.1016/j.learninstruc.2003.10.004

Wannapiron, P. (2014). Development of research-based blended learning model to enhance graduate students' research competency and critical thinking skills. In Procedia-Social and Behavioral Sciences, 136, 486-490. doi: https://doi.org/10.1016/j.sbspro.2014.05.361

Weil, L. G., Fleming, S. M., Dumontheil, I., Kilford, E. J., Weil, R. S., Rees, G., ... Blakemore, S. J. (2013). The development of metacognitive ability in adolescence. Consciousness and Cognition, 22(1), 264271. Doi: https://doi.org/10.1016/j.concog.2013.01.004

Whitebread, D., Coltman, P., Pasternak, D. P., Sangster, C., Grau, V., Bingham, S., ... Demetriou, D. (2009). The development of two observational tools for assessing metacognition and self-regulated learning in young children. Metacognition \& Learning, 4(1), 63-85. doi: https://doi.org/10.1007/s11409-008-9033-1

Wilson, J. S. (2017). Promoting Critical Thinking In General Biology Courses: The Case Of The White Widow 
Spider. Journal on Empowering Teaching Excellence Journal on Empowering Teaching Excellence Journal on Empowering Teaching Excellence, 1(2). Retrieved from https://digitalcommons.usu.edu/cgi/ viewcontent.cgi?article $=1011 \&$ context=jete

Yaliz, D. S. (2014). The metacognition levels of students: A research school of physical education and sports at Anadolu University. Journal of Human Sport and Exercise, 9, S398-S408. doi: https://doi.org/10. 14198/jhse.2014.9.Proc1.25

Zeichner, K. M. (2008). A critical analysis of reflection as a goal for teacher education. Educação \& Sociedade, 29, 535-554. doi: https://doi.org/10.1590/S0101-73302008000200012 